\title{
PERANCANGAN SISTEM INFORMASI PENGGAJIAN BERBASIS WEB DENGAN METODE WATERFALL PADA PT. SINAR METRINDO PERKASA (SIMETRI)
}

\author{
Ardianto Moenir ${ }^{1}$, Fajar Yuliyanto ${ }^{2}$ \\ ${ }^{1,2}$ Teknik Informatika, Fakultas Teknik, Universitas Pamulang \\ 1dosen00504@unpam.ac.id
}

\begin{abstract}
ABSTRAK
Gaji adalah suatu bentuk jasa yang diberikan secara teratur kepada seorang pegawai atas jasa dan hasil kerjanya. PT. Sinar Metrindo Perkasa (SIMETRI) adalah perusahaan yang bergerak dibidang produksi panel listrik. Dengan proses pengolahan data yang masih manual dengan menggunakan program bantu MS. Excel Hal ini menyebabkan terjadinya kesalahan perhitungan gaji karyawan, dan proses cetak slip gaji yang memakan waktu yang lama. Selain itu dalam pembuatan laporan penerimaan gaji setiap bulannya bagian HRD harus merekap dan memisahkan data gaji karyawan tetap dan karyawan kontrak yang kemudian diinput menjadi laporan gaji setiap bulannya. Hasil dari perancangan ini adalah sistem informasi penggajian karyawan berbasis web yang terkomputerisasi. Sehingga memudahkan kinerja perusahaan untuk pencatatan dan pelaporan penggajian karyawan. Hasil penelitian ini yaitu dihasilkannya sistem penggajian yang terkomputerisasi, memiliki standar aturan dalam proses pengembangan program sehingga mudah untuk dipelihara dan dikembangkan, serta $60 \%$ (persen) membantu meminimalisir kesalahan dalam memproses perhitungan gaji karyawan.
\end{abstract}

Kata Kunci: Penggajian, Waterfall, PHP, MySQL

\section{PENDAHULUAN}

Perkembangan teknologi informasi mengalami perkembangan yang sangat pesat dalam era globalisasi saat ini. Kejadian yang terjadi di suatu tempat dapat dengan cepat dan mudah diketahui di tempat lain di seluruh dunia. Kondisi ini tentunya mempengaruhi perilaku setiap individu yang ada dalam dunia usaha, kecepatan dan kemudahan perolehan informasi telah mendorong dunia usaha untuk memasuki era persaingan global

Sistem informasi digunakan untuk pengelolaan data dalam sebuah proses bisnis. Data - data yang diperlukan dalam sebuah proses bisnis dikelola dan diolah secara otomatis oleh sistem, agar kemudian dapat menjadi sebuah informasi yang dibutuhkan oleh pengguna. Sistem informasi diciptakan agar berbagai macam proses manual dapat dikerjakan secara komputerisasi sehingga lebih efektif dan efisien.

Sistem penggajian yang diterapkan kepada karyawan PT. Sinar Metrindo Perkasa (SIMETRI) masih dilakukan secara manual menggunakan program bantu MS. Excel, dimana perhitungan gaji karyawan masih menggunakan rumus di excel dan data - data

tersebut tidak disimpan ke dalam database. Sedangkan untuk mencetak slip gaji juga dilakukan manual karyawan satu per satu dan diperiksa kembali oleh bagian HRD.

Permasalahan yang terjadi pada sistem penggajian PT. Sinar Metrindo Perkasa (SIMETRI) saat ini antara lain data tidak tersimpan dengan baik karena belum menggunakan basis data, data gaji karyawan harus diperiksa berulang kali pada kolom kolom yang diisi dalam program bantu $M S$. Excel yang digunakan, terjadinya kesalahan perhitungan gaji karyawan, dan proses cetak slip gaji yang memakan waktu yang lama. Selain itu dalam pembuatan laporan penerimaan gaji setiap bulannya bagian HRD harus merekap dan memisahkan data gaji karyawan tetap dan karyawan kontrak yang kemudian diinput menjadi laporan gaji setiap bulannya.

Berdasarkan latar belakang ini maka perlu untuk membuat suatu sistem aplikasi yang diharapkan dapat mengelola semua permasalahan yang ada. "PERANCANGAN SISTEM INFORMASI PENGGAJIAN PADA PT. SINAR METRINDO PERKASA (SIMETRI) BERBASIS WEB DENGAN 
METODE WATERFALL" dibuat untuk membantu pemecahan persoalan dalam hal memberikan transparansi perhitungan gaji dari tiap penghasilan karyawan, serta membantu dalam mengelola sumber daya manusia yang terlibat didalamnya.

\section{METODE PENELITIAN}

Menurut Pressman (2015:42), model waterfall adalah model klasik yang bersifat sistematis, berurutan dalam membangun software. Nama model ini sebenarnya adalah "Linear Sequential Model". Model ini sering disebut juga dengan "Classic Life Cycle" atau metode waterfall. Model ini termasuk ke dalam model generic pada rekayasa perangkat lunak dan pertama kali diperkenalkan oleh Winston Royce sekitar tahun 1970 sehingga sering dianggap kuno, tetapi merupakan model yang paling banyak dipakai dalam Software Engineering (SE). Model ini melakukan pendekatan secara sistematis dan berurutan. Disebut dengan waterfall karena tahap demi tahap yang dilalui harus menunggu selesainya tahap sebelumnya dan berjalan berurutan.

Fase - fase dalam Waterfall Model menurut referensi Pressman :

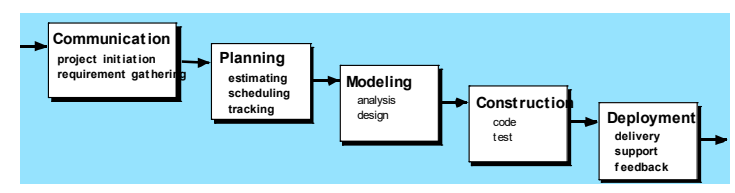

Gambar 2. 4 Fase Waterfall

Sumber: Roger S.Pressman

Model air terjun (waterfall) biasa disebut siklus hidup perangkat lunak. Mengambil kegiatan dasar seperti spesifikasi, pengembangan, validasi, evolusi dan merepresentasikan sebagai fase-fase proses yang berbeda seperti spesifikasi persyaratan, perancangan perangkat lunak, implementasi, pengujian dan seterusnya.

Keuntungan menggunakan metode waterfall adalah prosesnya lebih terstruktur, hal ini membuat kualitas software baik dan tetap terjaga. Dari sisi user juga lebih menguntungkan, karena dapat merencanakan dan menyiapkan kebutuhan data dan proses yang diperlukan sejak awal. Penjadwalan juga menjadi lebih menentu, karena jadwal setiap proses dapat ditentukan secara pasti.
Kelemahan menggunakan metode waterfall adalah bersifat kaku, sehingga sulit melakukan perubahan di tengah proses. Jika terdapat kekurangan proses/prosedur dari tahap sebelumnya, maka tahapan pengembangan harus dilakukan mulai dari awal lagi. Hal ini akan memakan waktu yang lebih lama. Karena jika proses sebelumnya belum selesai sampai akhir, maka proses selanjutnya juga tidak dapat berjalan.

\section{PEMBAHASAN}

Merupakan kegiatan menemukan atau mengidentifikasi masalah, mengevaluasi, membuat model serta membuat spesifikasi sistem dengan tujuan untuk merancang sistem baru atau memperbaiki kekurangan dari sistem yang telah ada.

Analisis merupakan suatu kegiatan yang bertujuan untuk mempelajari serta mengevaluasi suatu bentuk permasalahan yang ada pada sebuah sistem. Sedangkan sistem adalah suatu kesatuan yang utuh, terdiri dari dua atau lebih komponen yang saling berintegrasi dan beroperasi untuk mencapai tujuan tertentu dalam lingkungannya. Analisis sistem merupakan penggambaran, perencanaan sekaligus pembuatan sketsa dan beberapa peraturan dari elemen terpisah namun saling berintegrasi ke dalam suatu kesatuan yang utuh dan berfungsi.

Analisa sistem yang sedang berjalan secara keseluruhan sangat perlu bagi penulis untuk dapat mengetahui kelemahan dari sistem tersebut, baik dari cara kerja sistem maupun pihak pelaksananya dan segala sesuatu yang terlibat dalam sistem tersebut. Untuk pembuatan sistem informasi baru harus lebih terprogram dan terstruktur.

Berdasarkan observasi yang dilakukan penulis pada PT. Sinar Metrindo Perkasa (SIMETRI), dapat digambarkan mekanisme kerja sistem pada penggajian karyawan yang sedang berjalan yakni,

a. Karyawan digolongkan dengan jabatan masing - masing

b. Selanjutnya bagian HRD merekap data karyawan beserta jabatannya

c. Kemudian bagian HRD membuat laporan data jabatan dan data karyawan sebanyak 3 lembar, lembar pertama di serahkan kepada bagian keuangan, lembar kedua di serahkan kepada pimpinan, dan lembar ketiga disimpan bagian HRD sebagai arsip 
d. Dari laporan data jabatan tersebut bagian keuangan akan memeriksa laporan data karyawan untuk menyesuaikan dengan data gaji karyawan tersebut sesuai dengan jabatannya

e. Setelah sesuai, bagian keuangan akan menghitung gaji yang didapat karyawan yang disesuaikan dengan laporan jabatan dan data karyawan beserta tunjangan gaji karyawan

f. Setelah itu bagian keuangan menyesuaikan laporan penggajian dengan keuangan perusahaan

g. Setelah sesuai, bagian keuangan akan membuat slip gaji sesuai dengan laporan yang telah disetujui sebanyak 2 lembar, lembar pertama akan dijadikan arsip di bagian keuangan dan lembar kedua akan diserahkan pada bagian HRD yang kemudian diserahkan kepada karyawan

h. Kemudian bagian keuangan akan mencetak laporan keuangan sebanyak 2 lembar, lembar pertama akan dijadikan arsip pada bagian keuangan,sedangkan lembar kedua akan diserahkan kepada pimpinan

Berdasarkan gambaran sistem yang sedang berjalan pada PT. Sinar Metrindo Perkasa (SIMETRI), dapat digambarkan activity diagram pada penggajian karyawan yang sedang berjalan yakni,

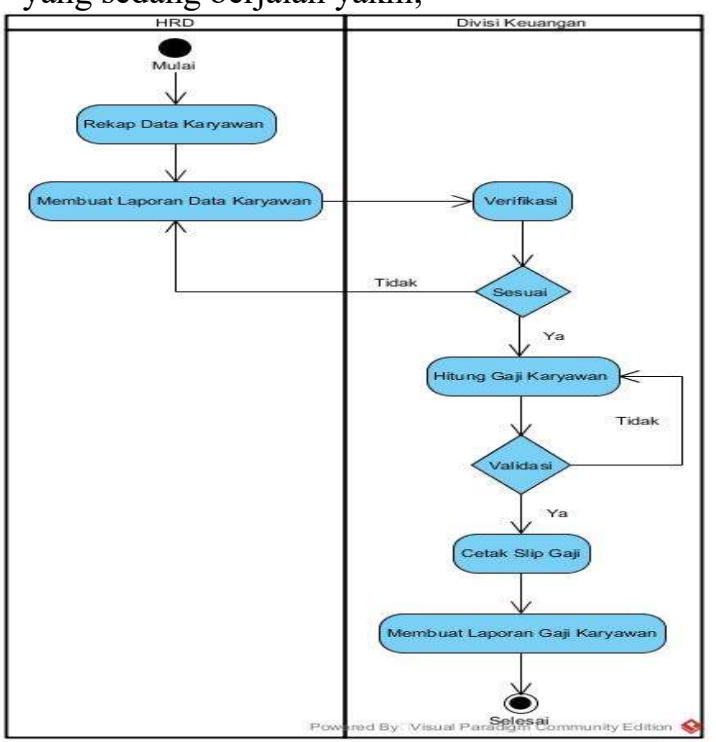

Gambar 3. 1 Activity Diagram Sistem Berjalan
Pada sistem ini diusulkan beberapa hal yang menjadi batasan masalah yang akan diberikan solusi atau alternatif dengan maksud menjelaskan tentang kebutuhan - kebutuhan yang harus dipenuhi oleh sistem yang akan dirancang, berdasarkan hasil analisa, maka dibuat suatu kebutuhan dalam perancangan. Memakai bahasa pemrograman PHP dan MySQL sebagai media penyimpanan datanya (database).

1. Kebutuhan:

Perhitungan gaji karyawan sesuai dengan golongan jabatan.

Masalah:

Untuk menghitung gaji karyawan sesuai dengan golongan jabatan masih melihat catatan keuangan perusahaan.

Usulan:

Perancangan system informasi penggajian karyawan dengan menggunakan bahasa pemrograman PHP dan MySQL.

2. Kebutuhan:

Laporan data penggajian karyawan. Masalah:

Proses pembuatan laporan penggajian karyawan maupun data karyawan membutuhkan prosedur yang cukup panjang.

Usulan:

Membuat sistem laporan penggajian karyawan secara terkomputerisasi.

3. Kebutuhan:

Penyimpanan data karyawan dan penggajian karyawan.

Masalah:

Media yang digunakan saat ini masih menggunakan alat bantu MS. EXCEL.

Usulan:

Membuat media penyimpanan dengan database MySQL.

Perancangan basis data bertujuan untuk diperolehnya basis data yang efisien, dalam penggunaan ruang penyimpanan, cepat dalam pengaksesan dan mudah dalam memanipulasi data serta bebas dari redudansi data.

\section{Normalisasi}

1. Unnormalisasi

Tabel 3. 1 Unnormalisasi 


\begin{tabular}{|l|c|c|l|}
\hline Nama Field & $\begin{array}{c}\text { Tipe } \\
\text { Data }\end{array}$ & Range & \multicolumn{1}{|c|}{ Deskripsi } \\
\hline Username & varchar & 50 & Username user \\
\hline Password & varchar & 50 & Password user \\
\hline Id_user & int & 11 & Id user \\
\hline nama & varchar & 50 & Nama user \\
\hline Id_karyawan & int & 11 & No id karyawan \\
\hline Nama & varchar & 50 & Nama karyawan \\
\hline Alamat & text & - & Alamat karyawan \\
\hline Jenis_kelamin & varchar & 10 & Jenis kelamin \\
\hline Nik & varchar & 20 & Nomor induk karyawan \\
\hline Username & varchar & 50 & Username karyawan \\
\hline Password & varchar & 50 & Password karyawan \\
\hline Id_pekerjaan & int & 11 & Id pekerjaan \\
\hline Pekerjaan & varchar & 30 & Nama pekerjaan \\
\hline Gapok & int & 11 & Gaji pokok \\
\hline Tukes & int & 11 & Tunjangan kesehatan \\
\hline Tutra & int & 11 & Tunjangan transportasi \\
\hline Tukel & int & 11 & Tunjangan keluarga \\
\hline Tupen & int & 11 & Tunjangan pendidikan \\
\hline Id_gaji & int & 11 & Id gaji karyawan \\
\hline tgl & date & - & Tanggal penggajian \\
\hline Agama & varchar & 20 & Nama agama \\
\hline Pendidikan & varchar & 50 & Jenjang pendidikan \\
\hline Asal_sekolah & varchar & 50 & Asal Sekolah \\
\hline N_perusahaan & varchar & 50 & Nama perusahaan \\
\hline Alamat & varchar & 50 & Alamat perusahaan \\
\hline Logo & varchar & - & Logo perusahaan \\
\hline Beranda & varchar & - & Kata pengantar beranda \\
\hline Prosedur & varchar & - & Prosedur pemakaian \\
\hline Admin & varchar & - & Hak akses \\
\hline
\end{tabular}

2. Normalisasi $1 \mathrm{NF}$

Tabel 3. 2 Normalisasi 1NF tabel user

\begin{tabular}{|l|c|c|l|}
\hline $\begin{array}{c}\text { Nama } \\
\text { Field }\end{array}$ & $\begin{array}{c}\text { Tipe } \\
\text { Data }\end{array}$ & \multicolumn{1}{|c|}{ Range } & \multicolumn{1}{|c|}{ Deskripsi } \\
\hline Username & varchar & 50 & Username user \\
\hline Password & varchar & 50 & Password user \\
\hline Nama & varchar & 50 & Nama user \\
\hline Id_user & int & 11 & Id user \\
\hline
\end{tabular}

Tabel 3. 3 Normalisasi 1NF tabel karyawan

\begin{tabular}{|l|c|c|l|}
\hline \multicolumn{1}{|c|}{ Nama Field } & $\begin{array}{c}\text { Tipe } \\
\text { Data }\end{array}$ & Range & \multicolumn{1}{|c|}{ Deskripsi } \\
\hline Id karyawan & int & 11 & No id karyawan \\
\hline Nama & varchar & 50 & Nama karyawan \\
\hline Alamat & text & - & Alamat karyawan \\
\hline Jenis_kelamin & varchar & 10 & Jenis kelamin \\
\hline Nik & varchar & 20 & Nomor induk karyawan \\
\hline Username & varchar & 50 & Username karyawan \\
\hline Password & varchar & 50 & Password karyawan \\
\hline
\end{tabular}

Tabel 3. 4 Normalisasi 1NF tabel pekerjaan

\begin{tabular}{|l|c|c|l|}
\hline Nama Field & $\begin{array}{c}\text { Tipe } \\
\text { Data }\end{array}$ & Range & \multicolumn{1}{|c|}{ Deskripsi } \\
\hline Id_pekerjaan & int & 11 & Id pekerjaan \\
\hline Pekerjaan & varchar & 30 & Nama pekerjaan \\
\hline
\end{tabular}

Tabel 3. 5 Normalisasi 1NF tabel gaji

\begin{tabular}{|l|c|c|l|}
\hline Nama Field & $\begin{array}{c}\text { Tipe } \\
\text { Data }\end{array}$ & Range & \multicolumn{1}{|c|}{ Deskripsi } \\
\hline Id_pekerjaan & int & 11 & Id pekerjaan \\
\hline Id_gaji & int & 11 & Id gaji karyawan \\
\hline tg1 & date & - & Tanggal Penggajian \\
\hline nik & varchar & 20 & Nomor induk karyawan \\
\hline Gapok & int & 11 & Gaji pokok \\
\hline Tukes & int & 11 & Tunjangan kesehatan \\
\hline Tutra & int & 11 & Tunjangan transportasi \\
\hline Tukel & int & 11 & Tunjangan keluarga \\
\hline Tupen & int & 11 & Tunjangan pendidikan \\
\hline
\end{tabular}

Tabel 3. 6 Normalisasi 1NF tabel agama

\begin{tabular}{|c|c|c|c|}
\hline $\begin{array}{c}\text { Nama } \\
\text { Field }\end{array}$ & $\begin{array}{c}\text { Tipe } \\
\text { Data }\end{array}$ & Range & Deskripsi \\
\hline Agama & varchar & 20 & Nama agama \\
\hline
\end{tabular}

Tabel 3. 7 Normalisasi 1NF tabel pendidikan

\begin{tabular}{|c|c|c|c|}
\hline $\begin{array}{c}\text { Nama } \\
\text { Field }\end{array}$ & $\begin{array}{c}\text { Tipe } \\
\text { Data }\end{array}$ & Range & Deskripsi \\
\hline Pendidikan & varchar & 50 & Jenjang pendidikan \\
\hline
\end{tabular}

Tabel 3. 8 Normalisasi $1 \mathrm{NF}$ tabel sekolah

\begin{tabular}{|l|c|c|l|}
\hline Nama Field & $\begin{array}{c}\text { Tipe } \\
\text { Data }\end{array}$ & Range & \multicolumn{1}{|c|}{ Deskripsi } \\
\hline Pendidikan & varchar & 50 & Jenjang pendidikan \\
\hline Asal_sekolah & varchar & 50 & Asal Sekolah \\
\hline
\end{tabular}

Tabel 3. 9 Normalisasi 1NF tabel perusahaan

\begin{tabular}{|l|c|c|l|}
\hline Nama Field & $\begin{array}{c}\text { Tipe } \\
\text { Data }\end{array}$ & Range & \multicolumn{1}{c|}{ Deskripsi } \\
\hline N_perusahaan & varchar & 50 & Nama perusahaan \\
\hline Alamat & varchar & 50 & Alamat perusahaan \\
\hline Logo & varchar & - & Logo perusahaan \\
\hline Beranda & varchar & - & Kata pengantar beranda \\
\hline Prosedur & varchar & - & Prosedur pemakaian \\
\hline Admin & varchar & - & Hak akses \\
\hline
\end{tabular}

\section{Normalisasi $2 \mathrm{NF}$}

Tabel 3. 10 Normalisasi 2NF tabel user

\begin{tabular}{|l|c|c|l|}
\hline $\begin{array}{c}\text { Nama } \\
\text { Field }\end{array}$ & $\begin{array}{c}\text { Tipe } \\
\text { Data }\end{array}$ & Range & \multicolumn{1}{|c|}{ Deskripsi } \\
\hline Username & varchar & 50 & Username user \\
\hline Password & varchar & 50 & Password user \\
\hline Id_user & int & 11 & Id user \\
\hline nama & varchar & 50 & Nama user \\
\hline
\end{tabular}

Tabel 3. 11 Normalisasi 2NF tabel karyawan

\begin{tabular}{|l|c|c|l|}
\hline Nama Field & $\begin{array}{c}\text { Tipe } \\
\text { Data }\end{array}$ & Range & \multicolumn{1}{|c|}{ Deskripsi } \\
\hline Id_karyawan & int & 11 & No id karyawan \\
\hline Nama & varchar & 50 & Nama karyawan \\
\hline Alamat & text & - & Alamat karyawan \\
\hline Jenis_kelamin & varchar & 10 & Jenis kelamin \\
\hline Nik & varchar & 20 & Nomor induk karyawan \\
\hline Username & varchar & 50 & Username karyawan \\
\hline Password & varchar & 50 & Password karyawan \\
\hline Agama & varchar & 20 & Nama agama \\
\hline Pendidikan & varchar & 50 & Jenjang pendidikan \\
\hline Asal_sekolah & varchar & 50 & Asal Sekolah \\
\hline Id_pekerjaan & int & 11 & Id pekerjaan \\
\hline
\end{tabular}

Tabel 3. 12 Normalisasi 2NF tabel pekerjaan

\begin{tabular}{|l|c|c|l|}
\hline Nama Field & $\begin{array}{c}\text { Tipe } \\
\text { Data }\end{array}$ & Range & \multicolumn{1}{|c|}{ Deskripsi } \\
\hline Id_pekerjaan & int & 11 & Id pekerjaan \\
\hline Pekerjaan & varchar & 30 & Nama pekerjaan \\
\hline Gapok & int & 11 & Gaji pokok \\
\hline Tukes & int & 11 & Tunjangan kesehatan \\
\hline Tutra & int & 11 & Tunjangan transportasi \\
\hline Tukel & int & 11 & Tunjangan keluarga \\
\hline Tupen & int & 11 & Tunjangan pendidikan \\
\hline
\end{tabular}

Tabel 3. 13 Normalisasi 2NF tabel gaji

\begin{tabular}{|l|c|c|l|}
\hline $\begin{array}{c}\text { Nama } \\
\text { Field }\end{array}$ & $\begin{array}{c}\text { Tipe } \\
\text { Data }\end{array}$ & Range & \multicolumn{1}{c|}{ Deskripsi } \\
\hline Id_gaji & int & 11 & Id gaji karyawan \\
\hline tgl & date & - & Tanggal Penggajian \\
\hline nik & varchar & 20 & Nomor induk karyawan \\
\hline
\end{tabular}

Tabel 3. 14 Normalisasi 2NF perusahaan 
ISSN 2541-1004

\begin{tabular}{|l|c|c|l|}
\hline Nama Field & $\begin{array}{c}\text { Tipe } \\
\text { Data }\end{array}$ & Range & \multicolumn{1}{|c|}{ Deskripsi } \\
\hline N_perusahaan & varchar & 50 & Nama perusahaan \\
\hline Alamat & varchar & 50 & Alamat perusahaan \\
\hline Logo & varchar & - & Logo perusahaan \\
\hline Beranda & varchar & - & Kata pengantar beranda \\
\hline Prosedur & varchar & - & Prosedur pemakaian \\
\hline Admin & varchar & - & Hak akses \\
\hline
\end{tabular}

(ERD)

Pada gambar dibawah menunjukan ERD dari Sistem Informasi Penggajian Karyawan pada PT. Sinar Metrindo Perkasa (SIMETRI), bahwa Admin dapat membuat banyak karyawan dan banyak laporan penggajian atau data karyawan, sedangkan satu karyawan mempunyai satu pendidikan dan dapat satu pekerjaan serta mendapatkan gaji sesuai jenis pekerjaan.

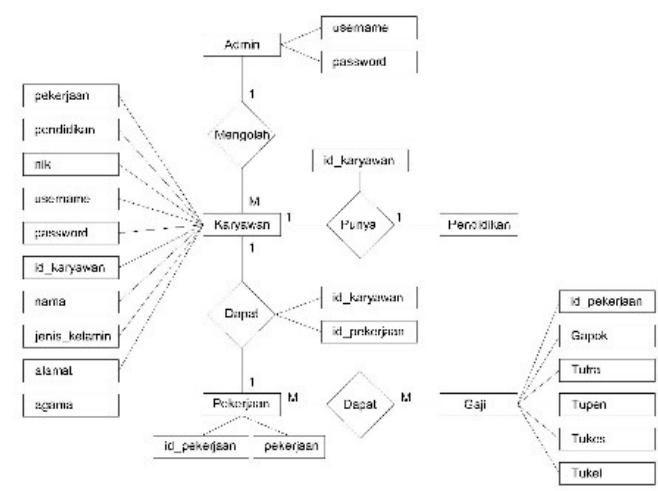

Gambar 3. 3 ERD Sistem Penggajian Karyawan

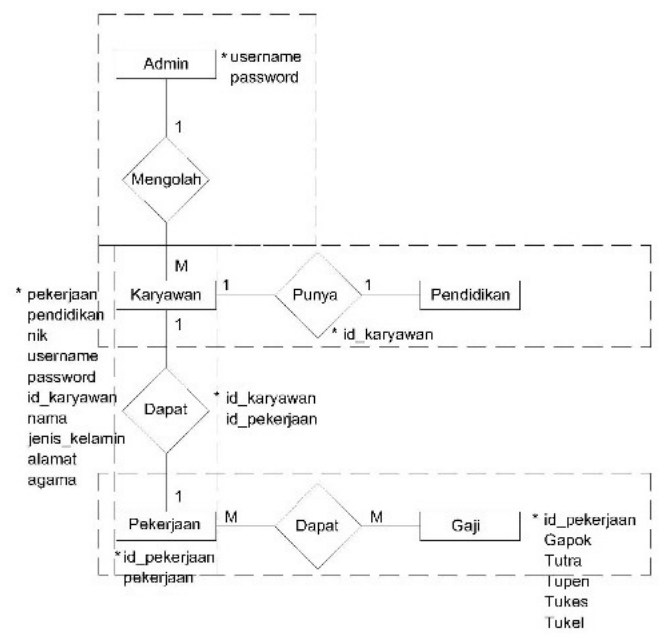

Gambar 3. 4 Transformasi ERD ke LRS

(LRS)

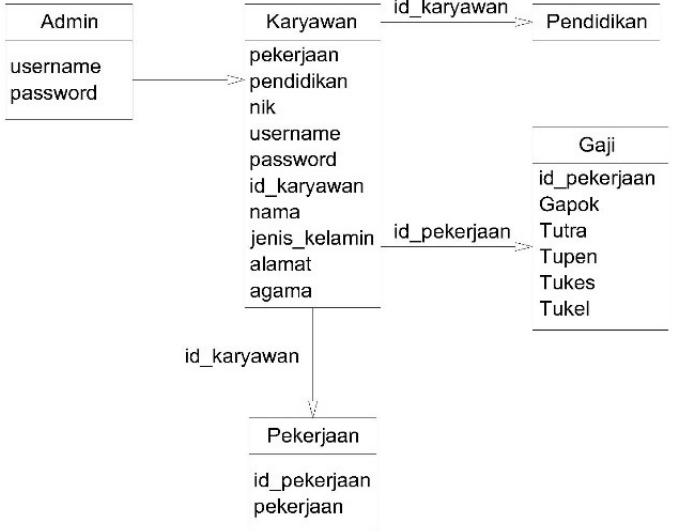

Gambar 3. 5 LRS Sistem Penggajian Karyawan

\section{Use Case Diagram}

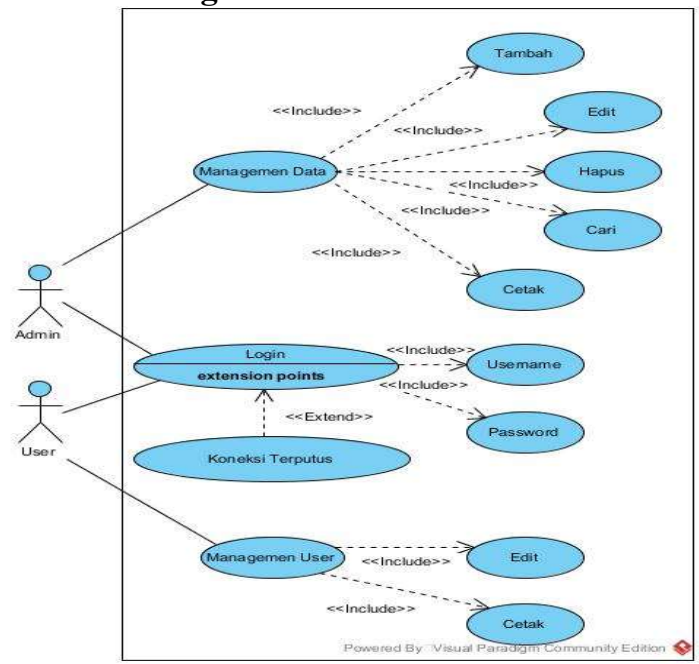

Gambar 3. 6 Use case Diagram

\section{Activity Diagram}

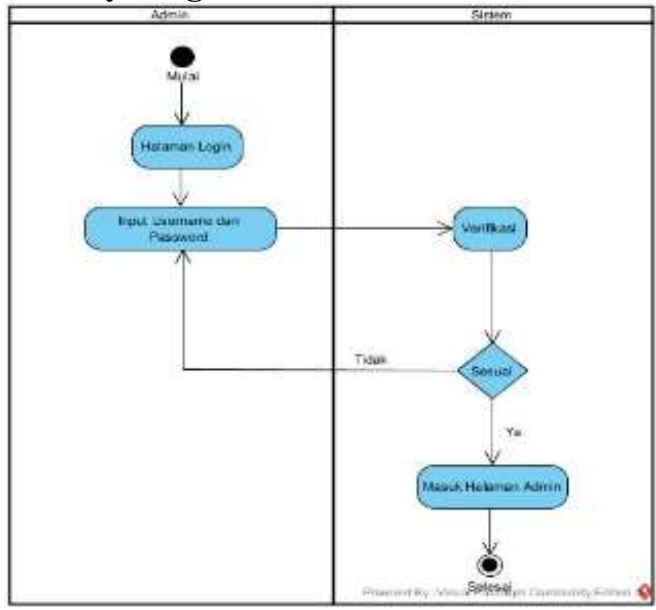

Gambar 3. 7 Activity Diagram Login Admin 


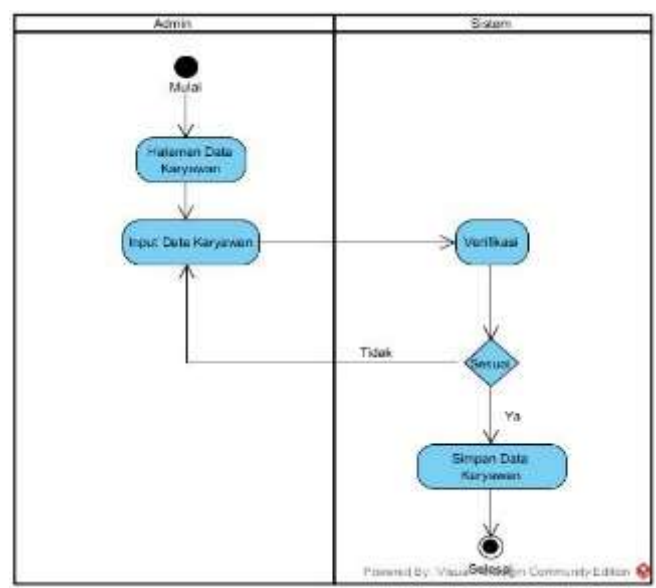

Gambar 3. 8 Activity Diagram Data Karyawan Admin

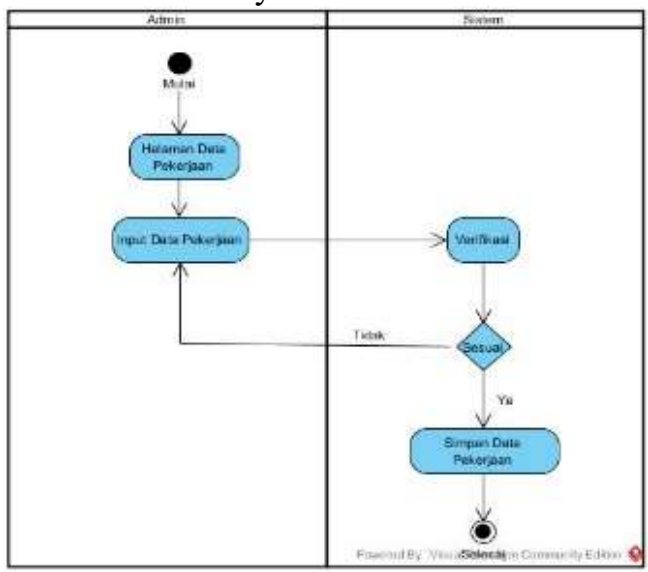

Gambar 3. 9 Activity Diagram Data Pekerjaan Admin

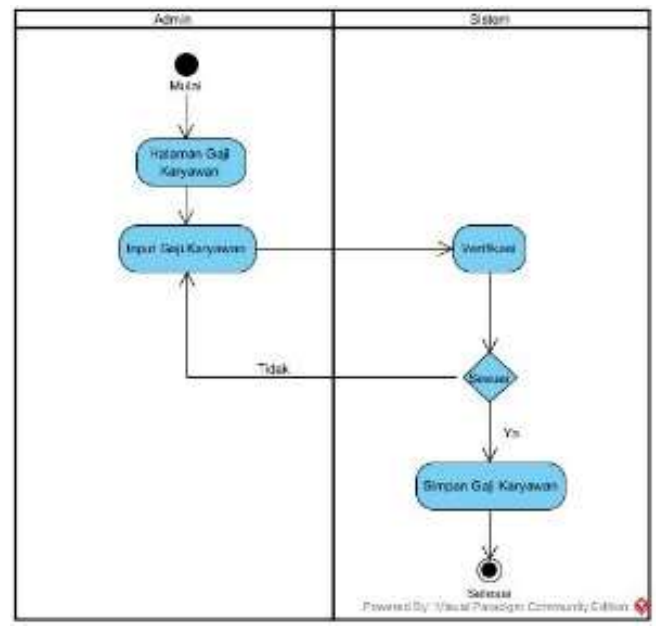

Gambar 3. 10 Activity Diagram Gaji Karyawan Admin

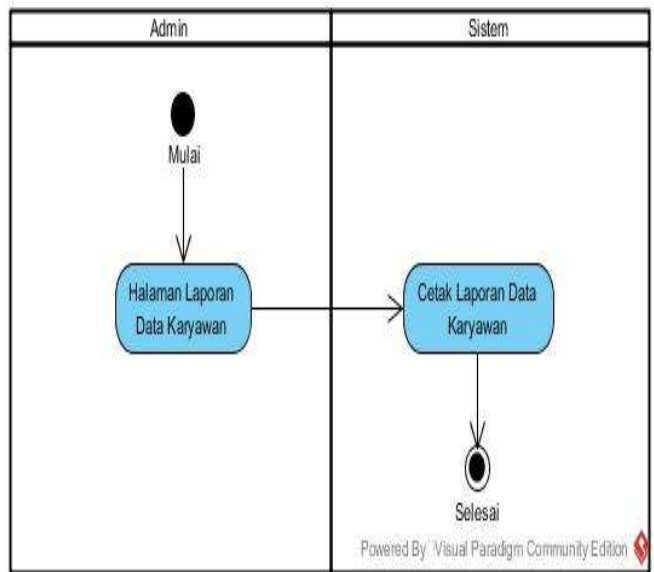

Gambar 3. 11 Activity Diagram Laporan Data Karyawan Admin

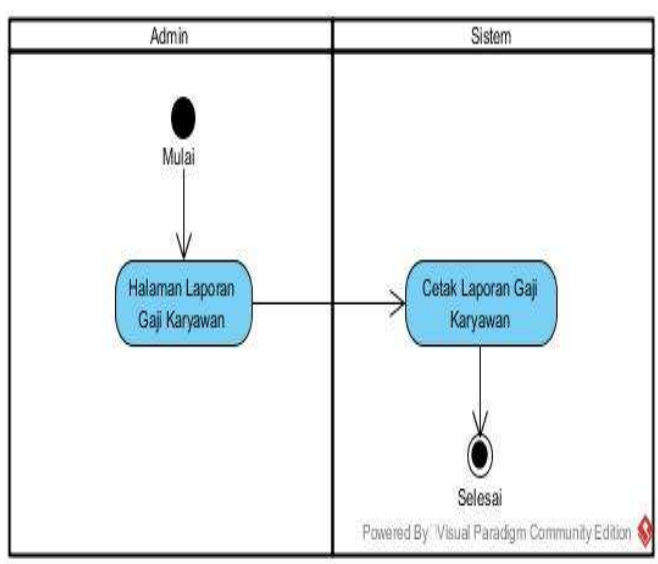

Gambar 3. 12 Activity Diagram Laporan Gaji Karyawan Admin

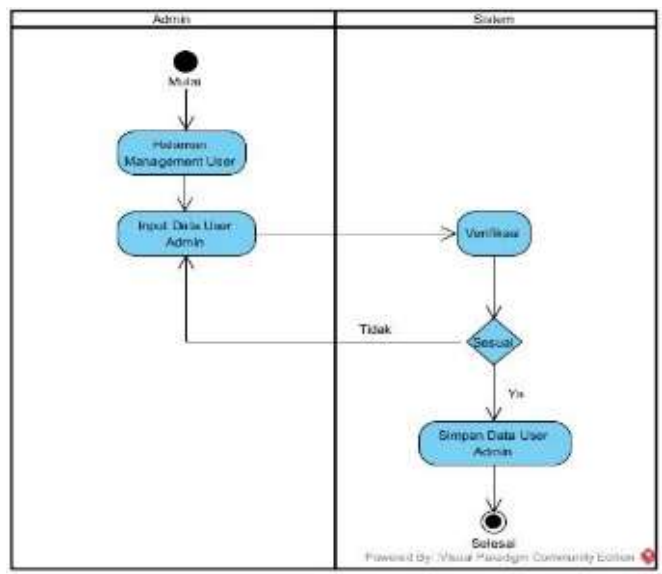

Gambar 3.13 Activity Diagram Managemen User Admin 


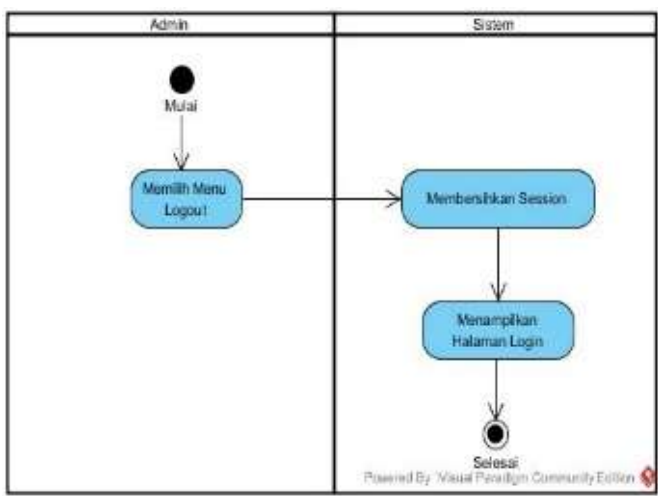

Gambar 3.14 Activity Diagram Logout Admin

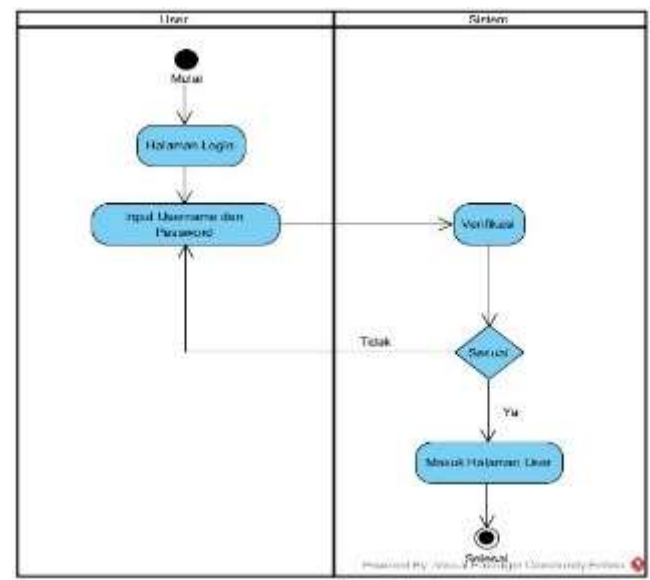

Gambar 3. 15 Activity Diagram Login User

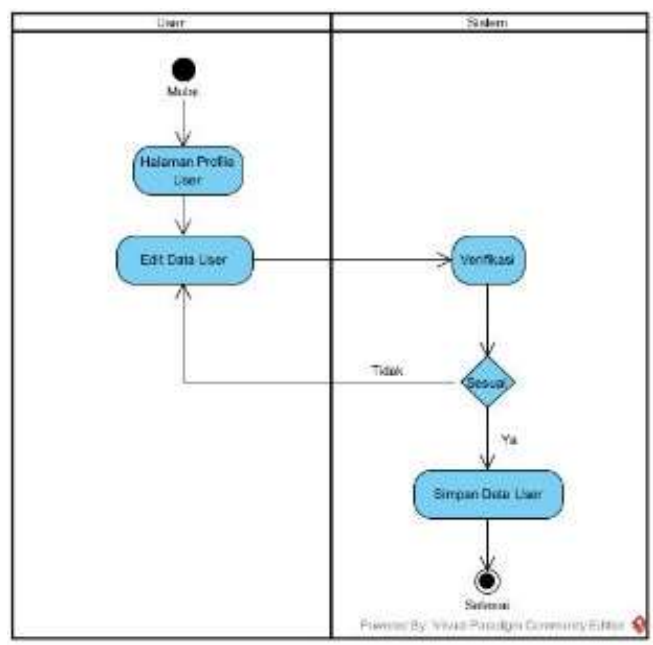

Gambar 3. 16 Activity Diagram Managemen Profile User

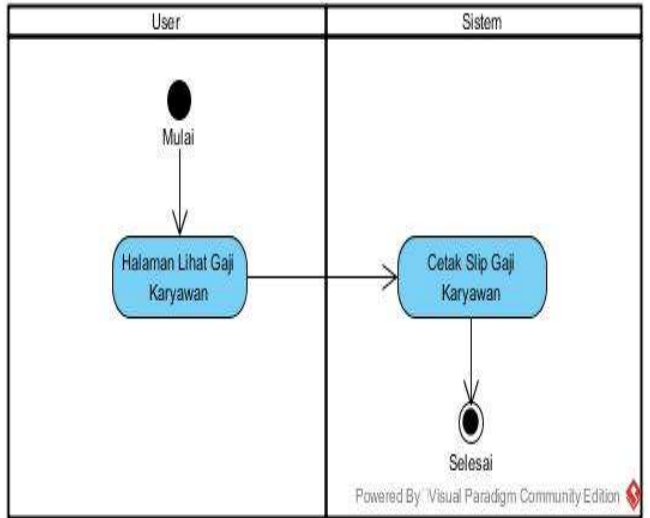

Gambar 3. 17 Activity Diagram Lihat Gaji User

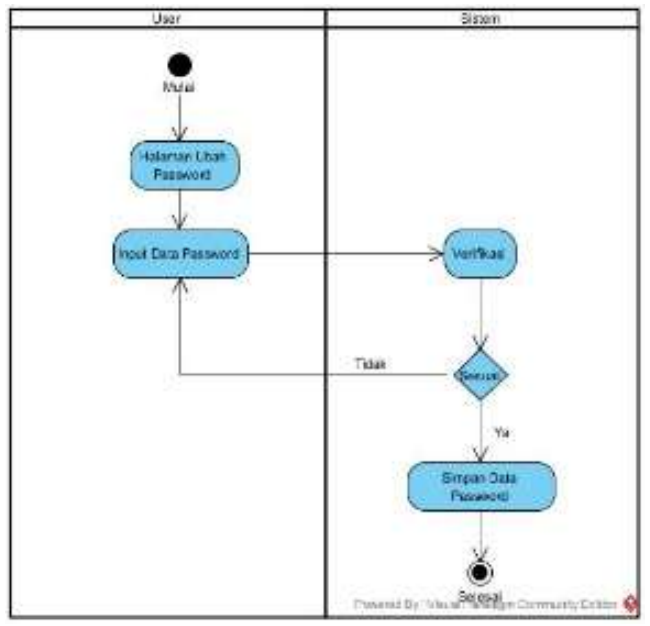

Gambar 3. 18 Activity Diagram Ubah Password User

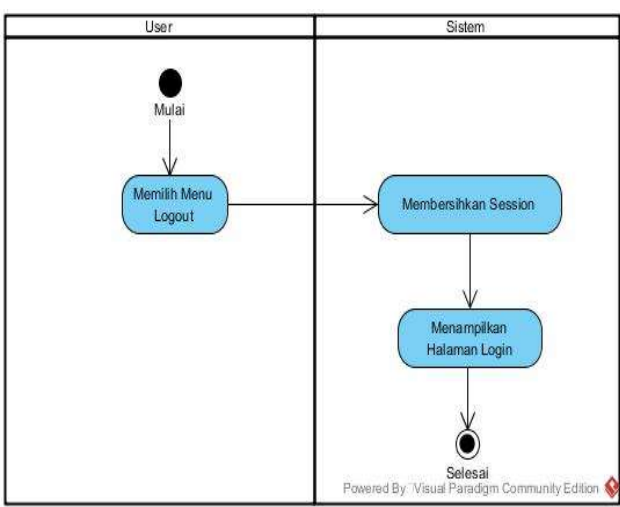

Gambar 3. 19 Activity Diagram Logout User

\section{Sequence Diagram}




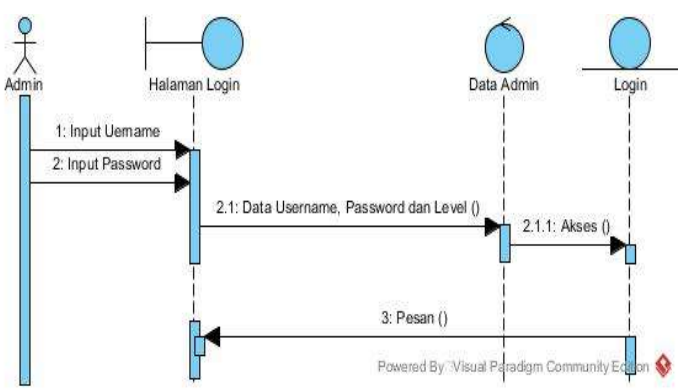

Gambar 3. 20 Sequence Diagram Login Admin

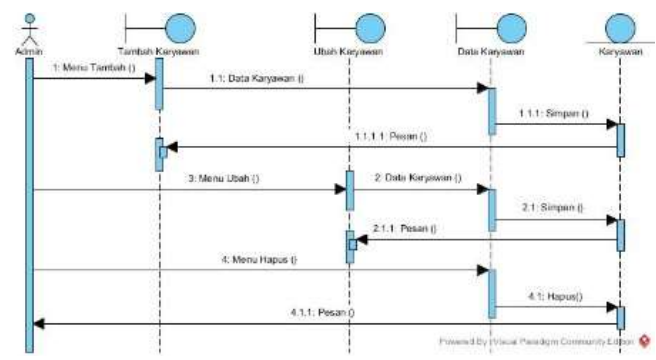

Gambar 3.21 Sequence Diagram Data Karyawan Admin

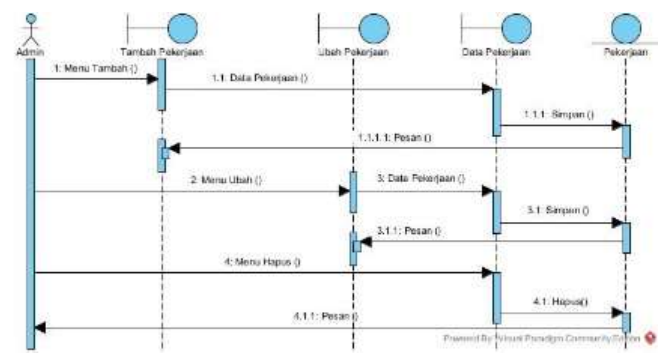

Gambar 3.22 Sequence Diagram Data Pekerjaan Admin

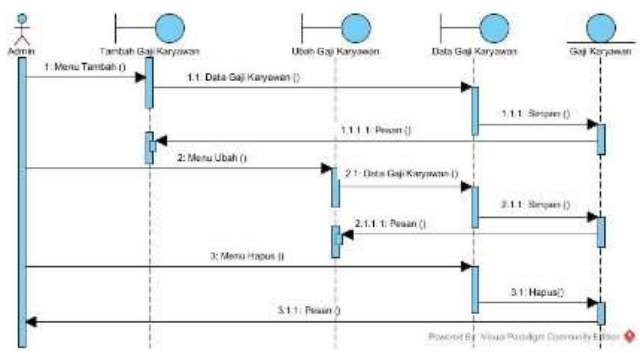

Gambar 3. 23 Sequence Diagram Gaji Karyawan Admin

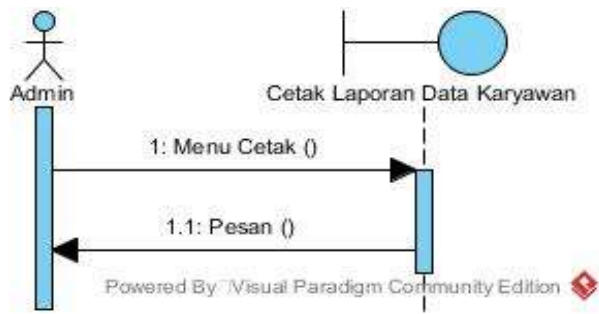

Gambar 3. 25 Sequence Diagram Laporan Data Karyawan Admin

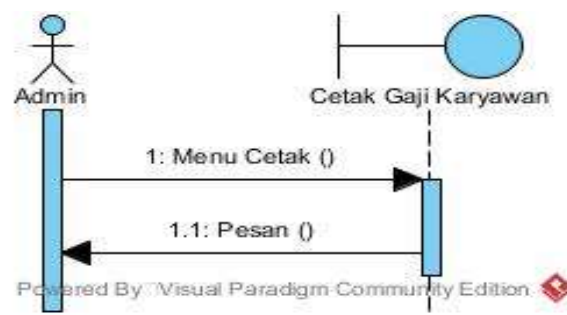

Gambar 3. 24 Sequence Diagram Laporan Gaji Admin

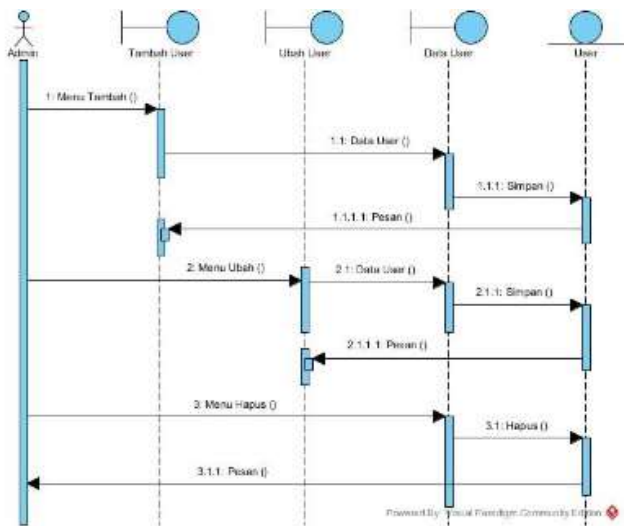

Gambar 3. 25 Sequence Diagram Managemen User Admin

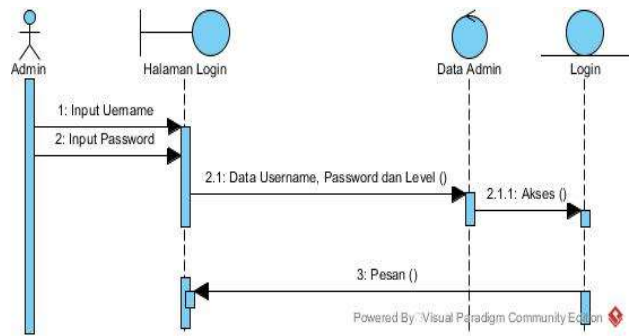

Gambar 3. 26 Sequence Diagram Logout Admin

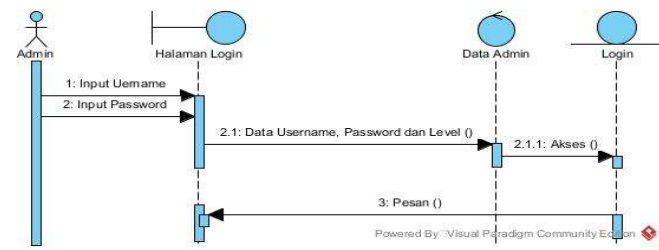

Gambar 3. 27 Sequence Diagram Login User

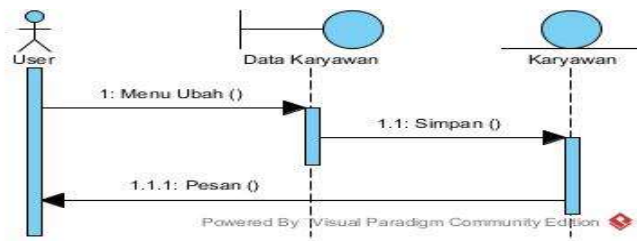


Gambar 3. 28 Sequence Diagram Profile User

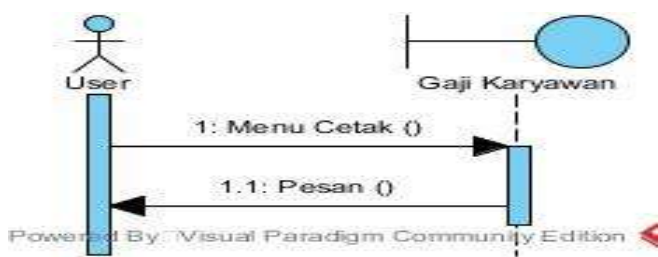

Gambar 3. 29 Sequence Diagram Lihat Gaji User

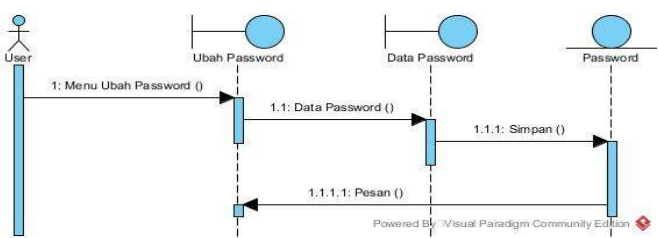

Gambar 3. 30 Sequence Diagram Ubah Password User

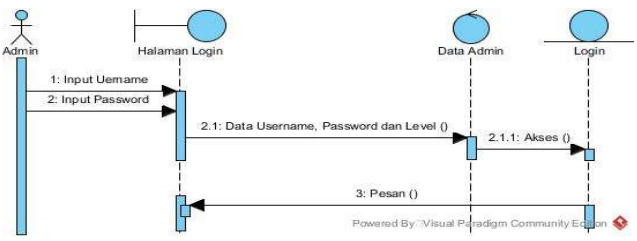

Gambar 3. 31 Sequence Diagram Logout User

\section{Class Diagram}

Penggambaran class diagram bertujuan untuk menampilkan kelas - kelas dan paket paket di dalam sistem informasi penggajian karyawan.Class diagram memberikan gambaran sistem secara statis dan relasi antar mereka. Biasanya, dibuat beberapa class diagram untuk sistem tunggal. Beberapa diagram akan menampilkan subset dari kelas kelas dan relasinya. Dapat dibuat beberapa diagram sesuai dengan yang diinginkan untuk mendapatkan gambaran lengkap terhadap sistem yang dibangun.

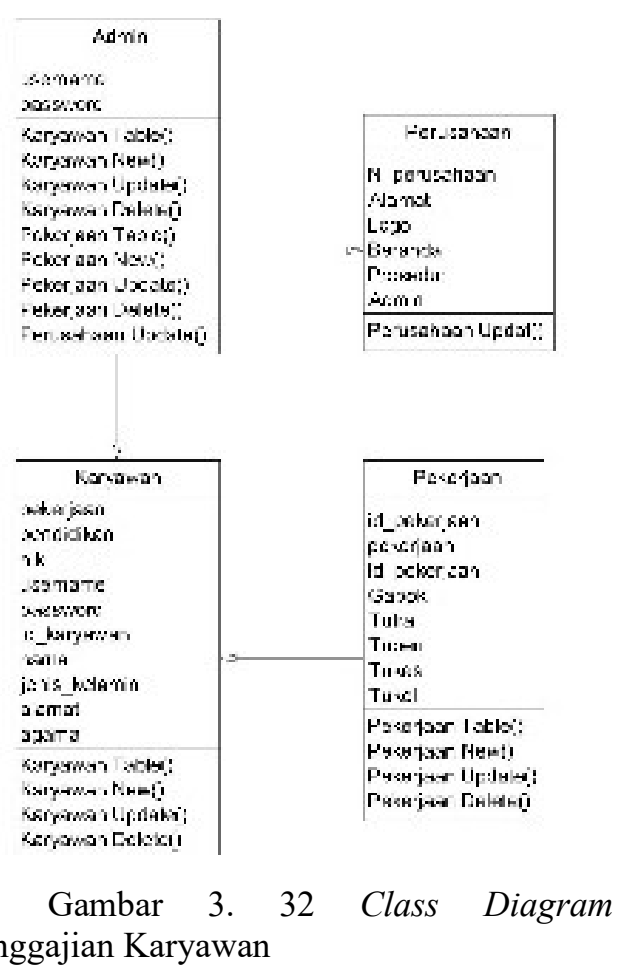

\section{Rancangan Tampilan (Interface)}

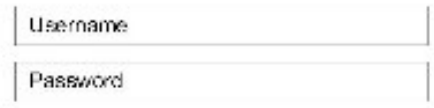

Lngin

Gambar 3. 33 Rancangan Tampilan Login

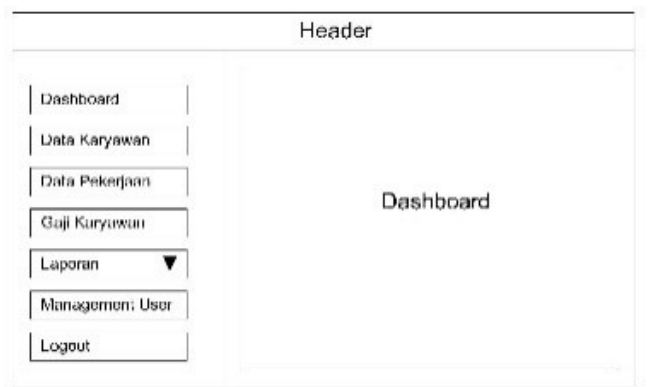

Gambar 3. 34 Rancangan Tampilan Dashboard Admin 


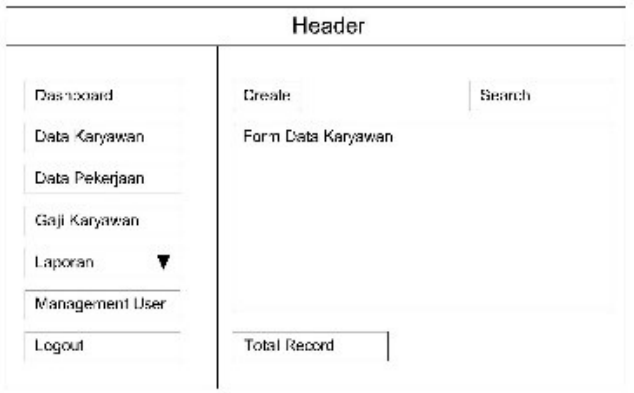

Gambar 3. 35 Rancangan Tampilan Data Karyawan Admin

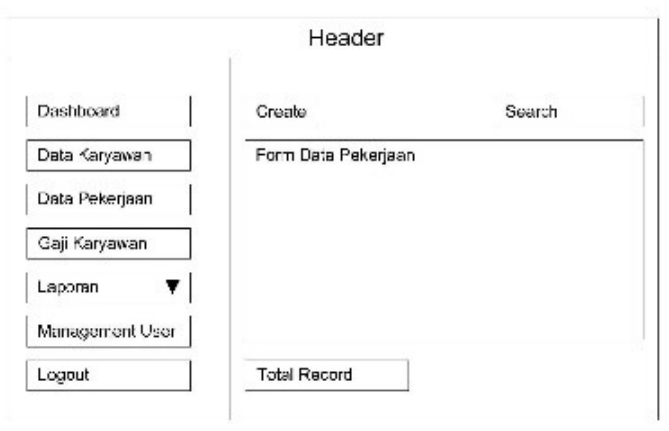

Gambar 3. 36 Rancangan Tampilan Data Pekerjaan Admin

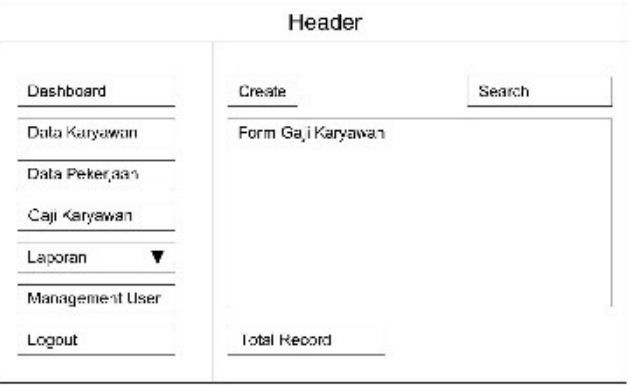

Gambar 3. 37 Rancangan Tampilan Gaji Karyawan Admin

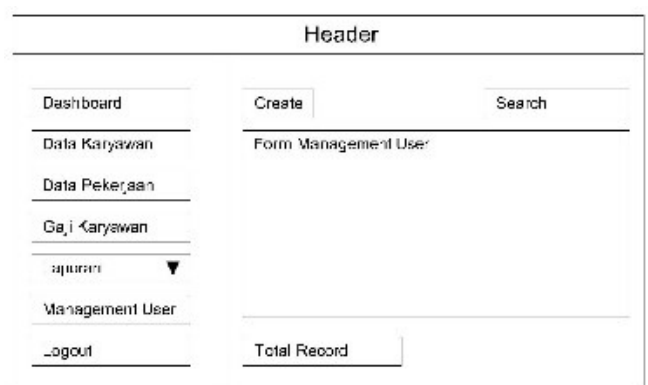

Gambar 3. 38 Rancangan Tampilan User Management Admin

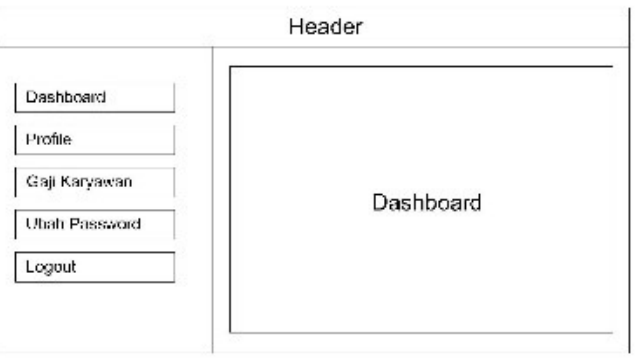

Gambar 3. 39 Rancangan Tampilan Dashboard User

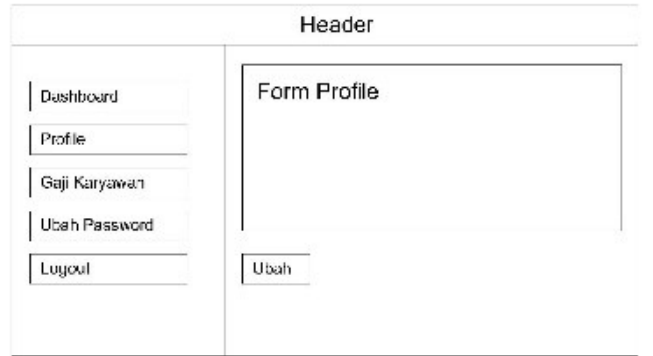

Gambar 3. 40 Rancangan Tampilan Profile User

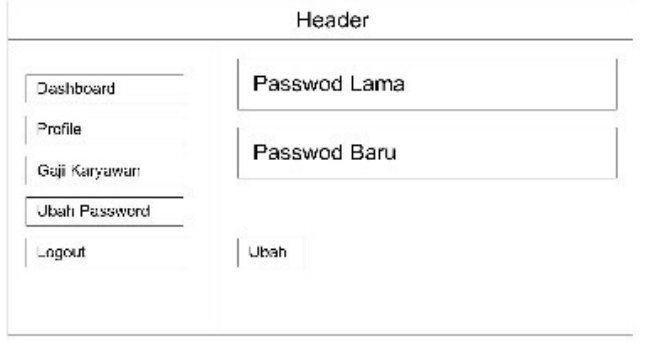

Gambar 3. 41 Rancangan Tampilan Ubah Password User

\section{KESIMPULAN}

Kesimpulan yang dapat diambil dari pembuatan Aplikasi Penggajian Karyawan pada PT. Sinar Metrindo Perkasa (SIMETRI) adalah sebagai berikut:

1. Dengan adanya sistem pengajian yang terkomputerisasi memudahkan perusahaan memperoleh data karyawan yang lebih terstrukur dan meminimalisir resiko kehilangan data karyawan karena sudah tersimpan didalam database dengan aman.

2. Dengan adanya penyimpanan data gaji karyawan pada PT. Sinar Metrindo Perkasa (SIMETRI) didalam database data gaji karyawan dapat tersimpan secara teratur.

3. Dengan adanya sistem penggajian pada PT. Sinar Metrindo Perkasa (SIMETRI) ini 
dapat meminimalisir kesalahan proses perhitungan penggajian yang ada.

\section{SARAN}

Berdasarkan perancangan sistem penggajian karyawan pada PT. Sinar Metrindo Perkasa (SIMETRI) yang telah dibuat, dapat diberikan saran untuk pengembangan sistem ini sebagai berikut:

1. Perancangan sistem penggajian karyawan ini sangat rentan terhadap penyalahgunaan data karena berbasis web dengan keamanan sederhana. Oleh karena itu, diperlukan backup data secara rutin.

2. Perancangan sistem penggajian karyawan ini hanya menampilkan data gaji yang belum sepenuhnya terintegrasi. Oleh sebab itu dalam pengembangan sistem selanjutnya, diperlukan integrasi dengan absensi agar data lebih mudah diperoleh dari karyawan dan dapat selalu update otomatis.

\section{DAFTAR PUSTAKA}

Kadir, A. (2013). Pengenalan Sistem Informasi (1st ed., Vol. I).

Yogyakarta, Indonesia: Andi Offset. Dipetik Oktober 19, 2017

Marnis, P. (2008). Managemen Sumber Daya Manusia. Sidoarjo: Zifatama Publisher.

Pressman, R. (2015). Rekayasa Perangkat Lunak: Pendekatan Praktisi Buku I. Yogyakarta: Andi Publisher.

Sunyoto, D. (2014). Sistem Informasi Managemen Perspektif Organisasi. Yogyakarta: CAPS.

Taufiq, R. (2013). Sistem Informasi Managemen. Yogyakarta: Graha Ilmu. 